
8 Research Square
Preprints are preliminary reports that have not undergone peer review.
They should not be considered conclusive, used to inform clinical practice, or referenced by the media as validated information.

\title{
Short-Term Field Research on Air Pollution within the Boundaries of the Large City in the Baltic Region
}

\author{
Aleksandras Chlebnikovas ( $\nabla$ aleksandras.chlebnikovas@vilniustech.lt) \\ Vilnius Gediminas Technical University: Vilniaus Gedimino Technikos Universitetas \\ https://orcid.org/0000-0002-6303-8802

\section{Dainius Paliulis} \\ Vilnius Gediminas Technical University: Vilniaus Gedimino Technikos Universitetas \\ Jolita Bradulienè \\ Vilnius Gediminas Technical University: Vilniaus Gedimino Technikos Universitetas

\section{Tomas Januševičius} \\ Vilnius Gediminas Technical University: Vilniaus Gedimino Technikos Universitetas
}

\section{Research Article}

Keywords: Air quality, gaseous pollutants, particulate matter, ammonia, city district.

Posted Date: May 27th, 2022

DOI: https://doi.org/10.21203/rs.3.rs-1178486/v2

License: (c) (1) This work is licensed under a Creative Commons Attribution 4.0 International License. Read Full License 


\section{Abstract}

Air quality in urban and suburban areas is strongly affected by the level of local urbanization, climatic conditions and industrial activity. Monitoring the main air pollutants such as nitrogen oxides, carbon monoxide and particulate matter may help control the most polluted areas of the site and take measures to reduce pollution. Uncontrolled emissions from other chemical pollutants, including volatile organic compounds and odorous contamination sources like ammonia may cause both a chronic human disease and damage to flora and fauna. The conducted field research is aimed at determining air pollution within the areas of the large city (residential territory, recreation territory and the areas close to intense transport streets) polluted with the gaseous pollutants of varying nature $\left(\mathrm{CO}, \mathrm{NO}_{2}\right.$, ozone, sulfur dioxide, $\mathrm{VOC}$ and $\mathrm{NH}_{3}$ ) as well as particulate matter in different seasons of the year. Studies on Vilnius district air quality were carried out in 17 urban locations (points) and based on two-phase measurements. The first phase was initiated in 2016-2017 and the second one took place in 2019-2020. It was observed that in the areas close to intense transport streets, the concentration of pollutants can increase more than 3 times, thus reaching up to $36.0 \mu \mathrm{g} / \mathrm{m}^{3}$ of PM10 (particulate matter) and up to $48.0 \mu \mathrm{g} / \mathrm{m}^{3}$ of nitrogen dioxide. During the summer period, ammonia concentrations can increase up to 3 times, reaching up to 11.0 $\mu \mathrm{g} / \mathrm{m}^{3}$ from farming and/or industrial activities.

\section{Introduction}

Environmental quality assessment is important both for evaluating and / or analysing the ecological situation and for the long-term forecast of changes in situational dynamics. The issue of ambient air quality remains particularly relevant in urban and suburban areas considering an annual growth in the population, urban area expansion, an increase in road traffic intensity and the emerging new sources of air pollution.

Significant changes in air quality due to a decline in the industrial scale caused by the global COVID-19 quarantine were assessed by (Kerimray et al., 2020). Changes were found to be less noticeable when the area was hardly urbanized and traffic flows were low. The performed studies showed that the level of primary pollution causes secondary pollution, which in turn exacerbates the environmental situation (Zheng et al., 2020). Thus, theoretical air pollution models estimating human migration have been developed for comparing the results of field research (Zeng \& Bao, 2021).

Air quality monitoring assists in taking control over possible environmental pollution. The level of air pollution determined with reference to field research findings provides the most accurate data on the situation of pollution in the investigated area. Only continuous selective monitoring of air pollution may provide the necessary information on identifying air pollution sources, reducing the resulting pollution and simulating the dispersion of air pollutants.

Road transport, energetic objects and industry are responsible for ambient air pollution. Polluted air is very noxious to human (Chen et al., 2012; Rushworth et al., 2014; Silva et al., 2013). Primary and 
secondary particulates are usually originated by natural sources such as wind-blown sands and sea spray particles. Main source of ambient air ozone is photochemical reaction of $\mathrm{NO}_{\mathrm{X}}$ and $\mathrm{VOCs}$ at sunlight. As for Lithuanian cities $\mathrm{NO}_{2}, \mathrm{SO}_{2}, \mathrm{PM}_{10}, \mathrm{CO}$ and $\mathrm{BTEX}$ are mainly those caused by industry, energetics and transport (lizuka et al., 2014). Air quality control is also performed for assessing the impact of air pollution on human health, the environment and climate in order to take necessary measures for protecting material, goods and living organisms. The EU Member States have defined maximum allowable levels (MACs) for some substances found in the air in the context of human health and plant protection. Council Directives - 2000/69/EC (Król et al., 2012; Pekey \& Yılmaz, 2011), 96/62/EC (Adema et al., 2012; Słomińska et al., 2014) and 2008/50/EC (Šerevičienė et al., 2014) are used for ambient air quality assessment and management. $\mathrm{NO}_{2}, \mathrm{SO}_{2}, \mathrm{CO}, \mathrm{O}_{3}, \mathrm{PM}_{10}$ and benzene values in ambient air were compared with limit values in line to 2008/50/EC directive. Toluene, ethylbenzene and xylenes (ortho, meta and para) are not included into the list of pollutants the amount of which in ambient air is regulated in agreement to European Union criteria.

Despite low quality of ambient air, monitoring of pollution is limited both in big urban areas and in small towns and rustic areas (Agrawal et al., 2021).

Lack of detailed data barely provides enough knowledge to determine the situation in the whole region.

Data on the Baltic region suggest that the use of coal as a fuel for households during the heating season is still remarkably widespread in the suburban area. The use of this type of fuel heavily pollutes the surrounding areas with carbon monoxide and carbon dioxide, sulfur dioxide and particulate matter (Wu et al., 2021). Particulate matter ( $\mathrm{PM}_{10}$ and $\mathrm{PM}_{2.5}$ in particular) contains a variety of pollutants, including sulphates, nitrates, ammonium salts, organic matter and heavy metals, causing significantly greater harm to human health than the traditional forms of pollutants (Xie et al., 2019).

Gaseous emissions $\left(\mathrm{SO}_{2}, \mathrm{NO}_{\mathrm{x}}\right.$ etc.) are important precursors of the secondary inorganic aerosols (SIAs), namely, sulfate $\left(\mathrm{SO}_{4}{ }^{2-}\right)$, nitrate $\left(\mathrm{NO}_{3}{ }^{-}\right)$and ammonium $\left(\mathrm{NH}_{4}{ }^{+}\right)$and could be emitted from stationary sources (fossil fuel combustion), ammonium emissions could be produced by livestock manure and fertilizer application.

Since the period of 1980s the level of $\mathrm{SO}_{\mathrm{x}}$ and $\mathrm{NO}_{\mathrm{x}}$ pollution was the highest in Eastern Europe. Althought the emissions are decreased significantly until now up to $80 \%$ (Davuliene et al., 2021).

The assessment of air pollution in urban areas is often limited to monitoring $\mathrm{CO}$ converted into $\mathrm{CO}_{2}$ greenhouse gases in the atmosphere. Acute and / or chronic diseases and even death are caused by $\mathrm{PM}_{2.5}, \mathrm{PM}_{10}$ and $\mathrm{SO}_{2}$ (Vanasse et al., 2017). The effects of nitrogen dioxide $\left(\mathrm{NO}_{2}\right)$ on the environment and human health are also harmful. In recent years, much attention has been paid to odorous pollutants caused by the contaminants arising from ammonia and volatile organic pollutants (VOCs) the most common of which are benzene, toluene, ethylbenzene and xylenes (BTEX). The intensity of the odours 
produced by the above introduced pollutants may vary subject to their concentrations and meteorological conditions (air temperature, wind direction and speed) and differ depending on the season of the year.

Air pollution measurements are frequently performed employing stationary and mobile devices. The latter are increasingly used due to equipment versatility. One of the most accurate, efficient and inexpensive techniques for determining air pollution presents the passive sorption method that applies to passive sorbents and allows examining air pollution conforming to the orientation of the pollution source in space. Passive sorbent exposure time ranges from two weeks to one month.

The maximum allowable levels defined for some substances and found in the air may cause a negative impact on human health and plants. Council Directives (2000/69/EC, 96/62/EC, 2008/50/EC) are used for ambient air-quality assessment and management. The concentrations of $\mathrm{CO}, \mathrm{NO}_{2}, \mathrm{SO}_{2}, \mathrm{PM}_{10}$ and benzene in ambient air were compared with limit values in line to the Directive on ambient air and cleaner air for Europe (2008/50/EC). Toluene, ethylbenzene, and xylenes (ortho, meta, and para), are not included into the list of pollutants the amount of which in ambient air is regulated as reported by the criteria established by the European Union. The pollutants have been regulated since 1 July 2007 in keeping to the national criteria for Lithuania. $\mathrm{CO}, \mathrm{NO}_{2}, \mathrm{SO}_{2}, \mathrm{O}_{3}, \mathrm{PM}_{10}$ and $\mathrm{BTEX}$ were assessed at sixteen different places in all directions in Vilnius district for a one-year period (September 2019 - June 2020) covering all seasons. Measurement points were chosen for evaluating ambient air quality.

Research aim. The principle objectives included quantitative analysis of the concentrations of $\mathrm{CO}, \mathrm{NO}_{2}$, $\mathrm{O}_{3}, \mathrm{SO}_{2}, \mathrm{PM}_{10}, \mathrm{BTEX}$ and $\mathrm{NH}_{3}$ in the areas close to potential emission sources and surrounding the Vilnius district. To assess the variation of pollution due to location, seasonality and evaluate the determined correlation between pollutants, taking into account the main groups of zones within the residential, recreation and close to intense transport streets.

\section{Methodology \\ 2.1. Study area}

The study was carried out in Vilnius district, Eastern Europe, Lithuania and counted four permanent air quality monitoring places installed in the city (three places were set up close to the intense traffic road and one in the Old Town). No monitoring place was established on the cityside or in the district.

In line to Lithuanian State Enterprise Centre of Registers, a population of 106957 inhabited Vilnius district in 2021. The area of Vilnius district covers $2129 \mathrm{~km}^{2}$.

The average perennial climatic data on Vilnius district show a temperature of $-5.5^{\circ} \mathrm{C}$ in January (winter / cold period), a temperature of $+18.0^{\circ} \mathrm{C}$ in July (summer / warm period) and approximate annual of $7.0^{\circ} \mathrm{C}$ under the precipitation of $640 \mathrm{~mm}$ (annual). 
Studies on air quality in Vilnius district were conducted in 17 urban locations (points). The map of the selected points in Vilnius district is given in Fig. 1.

Vilnius district municipality is one of the largest municipalities in Lithuania. The area occupies 2129 square $\mathrm{km}$ area and is divided into 23 elderships. The district from the north, south and east surrounds the Lithuanian capital Vilnius, with a developed public and business, rural infrastructure, is able to harmonize and develop dynamically, attract new investment and ensure a high quality of life and environment for everyone. The territory of Vilnius district borders on the Republic of Belarus in the east. Vilnius district is dominated by rural areas (a total of 1,163 villages). The number of people living in villages in Vilnius district reaches 95 percent. municipal population, while on average in Lithuania 33 percents population lives in villages; the population of Vilnius district was 100146 citizens in 2020 year.

17 measurement points (including one for ammonia) were selected as representing recreation, residential and transport impact territories in Vilnius district. 1 point was selected to analyse the impact of potential pollution from poultry farming industry. The description of all measurement points is presented in Table 1. The location of the points was chosen according to the location of the largest towns and settlements in terms of population, and their number was chosen in proportion to the number of inhabitants, the main sources of pollution, among which the most distinguished roads are motorways. The aim was to carry out studies in different types of zones, the location of which is as close as possible, with the possibility to compare their pollution results with each other and to assess the source of the pollution. 
Table 1

Measurement points

\section{[No of the points], coordinates}

\begin{tabular}{lll}
\hline Residential territory & Recreation territory & $\begin{array}{l}\text { Areas close to intense } \\
\text { transport streets }\end{array}$ \\
$\begin{array}{l}\text { [02] Residential quarter, traffic } \\
\text { pollution }\end{array}$ & $\begin{array}{l}\text { [07] Residential quarter, traffic } \\
\text { pollution }\end{array}$ & $\begin{array}{l}\text { [01] Residential Quarter, } \\
\text { impact of road pollution }\end{array}$ \\
$\begin{array}{l}\text { [03] Residential quarter, traffic } \\
\text { pollution }\end{array}$ & $\begin{array}{l}\text { [012] Residential quarter, } \\
\text { traffic pollution }\end{array}$ & $\begin{array}{l}\text { [05] Residential Quarter, } \\
\text { industrial and transport } \\
\text { pollution }\end{array}$ \\
\hline $\begin{array}{l}\text { [04] Residential Quarter, pollution } \\
\text { from road and rail transport }\end{array}$ & $\begin{array}{l}\text { [016] Residential Quarter, } \\
\text { industrial and transport } \\
\text { pollution }\end{array}$ & $\begin{array}{l}\text { [O6] Residential Quarter, } \\
\text { industrial and transport } \\
\text { pollution }\end{array}$ \\
\hline
\end{tabular}

[08] Traffic pollution

[010.1] Northern side of the airport

[09] Residential Quarter,

background concentration

[010.2] Western side of the airport

[013] Residential Quarter, pollution from road and rail transport.

[010.3] Southern side of the airport

[014] Residential quarter, traffic pollution

[010.4] Eastern side of the airport

[011] Residential Quarter, industrial and transport pollution

[015] Residential quarter, traffic pollution

Ammonia

[017.1] Northern side of poultry farming $54.593489,25.339479$ (apartment buildings)

[017.2] Eastern side of poultry farming 54.594855, 25.342759 (areas close to the gymnasium and kindergarten)

[017.3] Northern side of poultry farming $54.594808,25.342757$ (private household blocks)

[017.4] Eastern side of poultry farming 54.591372, 25.339574 (private household blocks)

First air quality measurements were carried out from June 2016 to March 2017. The second phase of the research was conducted from September 2019 to June 2020. 
The air polluted with $\mathrm{NH}_{3}$ was measured at SC Vilniaus Paukstynas, a potential source of an unpleasant odour in the area of Vilnius District Municipality (Fig. 1b, Table 1).

The air quality assessment period is presented in Table 2. The concentrations of gaseous pollutants (CO, $\mathrm{NO}_{2}, \mathrm{SO}_{2}, \mathrm{O}_{3}$ ) were detected at a mobile laboratory applying analysers. BTEX and $\mathrm{NH}_{3}$ were analysed employing the diffusive sampling method, and the concentration of solid pollutants $\mathrm{PM}_{10}$ was calculated using analyser MP101M. The experiments were carried out continuously for each pollutant three times per measurement point and/or exposing three parallel diffusive samplers.

Table 2

Air quality within the Vilnius district assessment period

\begin{tabular}{|c|c|c|}
\hline Season & Pollutant & Period of measurements \\
\hline \multirow[t]{2}{*}{ Autumn } & $\mathrm{CO}, \mathrm{NO}_{2}, \mathrm{SO}_{2}, \mathrm{O}_{3}, \mathrm{PM}_{10}$ & 6 September 2019-18 September 2019 \\
\hline & BTEX, Ammonia & 11 September 2019-25 September 2019 \\
\hline \multirow[t]{3}{*}{ Winter } & $\mathrm{CO}, \mathrm{NO} 2, \mathrm{SO} 2, \mathrm{O} 3, \mathrm{PM}_{10}$ & 22 March 2016-29 March 2016; \\
\hline & & 20 January 2020-29 February 2020 \\
\hline & BTEX, Ammonia & 22 January 2020-5 February 2020 \\
\hline \multirow[t]{2}{*}{ Spring } & $\mathrm{CO}, \mathrm{NO} 2, \mathrm{SO} 2, \mathrm{O}, \mathrm{PM}_{10}$ & 1 April 2020-10 April 2020 \\
\hline & BTEX, Ammonia & 1 April 2020-15 April 2020 \\
\hline \multirow[t]{3}{*}{ Summer } & $\mathrm{CO}, \mathrm{NO} 2, \mathrm{SO} 2, \mathrm{O} 3, \mathrm{PM}_{10}$ & 22 June 2016-29 June 2016; \\
\hline & & 15 June 2020-25 June 2020 \\
\hline & BTEX, Ammonia & 16 June $2020-30$ June 2020 \\
\hline
\end{tabular}

Following exposure, diffusion samplers were analysed in an accredited laboratory of Gradko JSC (Great Britain) thus determining the quantity of BTEX and $\mathrm{NH}_{3}$ (Lithuanian Air Monitoring System, 2010). Tube made from polymer fitted with thermoplastic rubber caps. The cap contains the absorbent. A one-micros porosity filter is fitted to absorb the pollutant. All diffusion samplers are suitable for carrying out spatial or localized assessments for specific pollutant in ambient air. Typical exposure periods is $2-4$ weeks. In line to air quality directive 2008/50/EC, the results of indicative measurements shall be considered for assessing air quality with respect to limit values. For indicative measurements, minimum time coverage is $14 \%$ that provides 8 weeks evenly distributed over the year. Time for applied measurements was in consonance to the established requirements. Therefore, the obtained results can be compared with the defined limits for the measured pollutants. The samplers in casings were fixed at $3-4 \mathrm{~m}$ above the ground. The area of sampling exposure was open, free from buildings, trees and other objects and at least $1 \mathrm{~m}$ from any structures that could disrupt airflow. $\mathrm{PM}_{10}$ was measured applying the beta radiation absorption (ISO 10473) method on Environment S.A. Model MP101M PM 10 Beta Gauge Monitor (France) 
device for a period of $8 \mathrm{~h}$ at an average flow rate of $1.0 \mathrm{~m}^{3} /$ hour. At each measurement point, an average value of $\mathrm{PM}_{10}$ was calculated.

The settlement of Rudamina has been selected as the area where the main poultry company of Vilnius city operates and as one of air quality measurement points. The residents of the settlement constantly make complaints about unpleasant odours emitted from the object, which dramatically increases during the summer period. The relevant studies provide that the current odour standardization is regulated by the Lithuanian Hygiene Standard HN 121:2010 Limit Value of the Odour Concentration in the Residential Ambient Air and The Regulations of Odour Control in the Residential Ambient Air. As reported by the introduced documents, the limit value is equal to 8 oue $/ \mathrm{m}^{3}$ (European odour units). In the future, the value is expected to rise and make as high as 5 oue $/ \mathrm{m}^{3}$. Thus, ammonia concentration was estimated every three months next to the measurement point of residential blocks or private households downwind of the poultry house as the potential source of air pollution.

\section{Statistical Analysis and Data Quality}

Three samples were taken at each measurement point. A blank sample was used as a control unit. Descriptive statistical analysis was employed (mean, standard deviation interval and Pearson coefficient) applying Excel 2016. The significance of association (p) was accepted as statistically significant at the alpha level of $<0.05$. The place, height and duration of sampling, storing and transporting samples were carried out conforming to requirements for standards. Accredited laboratory Gradko JSC (Great Britain) analysed the obtained air samples.

\section{Results And Discussion}

The research findings of air pollution in the area of Vilnius District Municipality have been compared considering all seasons, including autumn 2019 and winter-summer 2020. The investigation of the concentrations of pollutants were performed once a season. The presented figures provide only the number of the research site without further detail, and the obtained results are grouped at the measurement points in residential and recreation territories and those next to heavy traffic roads respectively.

In 2019, Lithuania calculated an average of 466 cars per 1,000 inhabitants. The number of cars in both Lithuania and Vilnius district grows every year thus increasing air pollution, however, stricter requirements for the amounts of pollutants (latest euro standards) emitted from cars into ambient air are reducing emissions. Rising pollution caused by road transport is successfully reduced through the replacement of gravel roads with hard road surfaces and watering the streets of cities. Also, making detours decreases a negative impact of transport on human health. Air pollution from rail transport is cut electrifying certain railway lines conforming to the EU standards and tightening standards limiting the concentrations of the pollutants emitted by rolling stock into the air. 
Variations in the concentration of particulate matter $\left(\mathrm{PM}_{10}\right)$ are shown in Fig. 2 and Table 3.

Table 3

Particulate matter $\left(\mathrm{PM}_{10}\right)$ concentration (in $\mu \mathrm{g} / \mathrm{m}^{3}$ ) measured in the areas close to intense transport streets

\begin{tabular}{|lllllll|}
\hline Season/Point & [01] & [05] & [06] & [010] & [011] & [015] \\
\hline Winter & 31.6 & 14.8 & 9.4 & 18.3 & 10.2 & 33.0 \\
\hline Spring & 23.3 & 12.0 & 34.5 & 33.3 & 10.8 & 6.6 \\
\hline Summer & 12.9 & 26.3 & 6.2 & 3.2 & 20.8 & 13.7 \\
\hline Autumn & 4.2 & 23.8 & 26.4 & 20.2 & 36.0 & 7.4 \\
\hline $\begin{array}{l}\text { Annual limit value for the protection of human } \\
\text { health }\end{array}$ & 40 & & & & & \\
\hline
\end{tabular}

Emissions from car traffic or increased pollution is one of the main sources of pollution with particulate matter in the open environment. The conducted studies have disclosed increased $\mathrm{PM}_{10}$ concentration in the highest intensity roads compared to the findings received in other types of zones where the values ranged from 20.2 to $36.0 \mu \mathrm{g} / \mathrm{m}^{3}$, standard deviation (SD) was equal to $1-1.8 \mu \mathrm{g} / \mathrm{m}^{3}$. The demonstration of passive sorbents took place prior to the heating season in the early autumn, and thus the effects of additional pollution were avoided. $\mathrm{PM}_{10}$ concentration was very low at some measurement points related to transport units and varied between 4.2 and $7.4 \mu \mathrm{g} / \mathrm{m}^{3}$ (No 1 and 15), which was caused by the decreased flows of cars (5-36 pcs) and heavy vehicles (up to 6 pcs) determined within a period of 1 hour, SD was equal to up to $0.4 \mu \mathrm{g} / \mathrm{m}^{3}$. During the winter season, the concentrations of all tested pollutants dropped by no more than 1.6 times, and $\mathrm{PM}_{10}$ concentration was highest compared to the annual average. During the wintertime, additional pollution was initiated by the activity of district boilers used for heating, and traffic flows decreased by approximately $20-30 \%$ (compared to the autumn season). As for the urban area, heat energy for multi-apartment buildings and a part of individual residential houses was supplied from centralized district heating energy systems. However, most of the residential houses are individually heated by gas or solid fuel boilers. In Vilnius district, natural gas used for heat production makes up around $78 \%$ of fuel balance, whereas coal takes $11 \%$ and the rest is biofuel and liquefied gas.

Emission results changed moderately comparing the results of monitoring in 2016 and those for the period of 2019-2020. $\mathrm{PM}_{10}$ concentration varied from 8.7 to $39.1 \mu \mathrm{g} / \mathrm{m}^{3}$ with an average value of 18.71 $\mu \mathrm{g} / \mathrm{m}^{3}$ (SD was equal to $0.9 \mu \mathrm{g} / \mathrm{m}^{3}$ ), i.e., only 1.015 times lower than that in 2019-2020. The minimum value of $\mathrm{PM}_{10}$ concentration was equal to $8.7 \mu \mathrm{g} / \mathrm{m}^{3}$ (summer average value made $13.03 \mu \mathrm{g} / \mathrm{m}^{3}$ ) in June 2016 and a maximum of $39.1 \mu \mathrm{g} / \mathrm{m}^{3}$ (winter average value reached $24.39 \mu \mathrm{g} / \mathrm{m}^{3}$ ) was detected in March 2016. Overall, $100 \%$ recorded values of $\mathrm{PM}_{10}$ were found within the permissible limit of $40 \mu \mathrm{g} / \mathrm{m}^{3}$ unlike the case in April 2020 with four results that exceeded. The average $\mathrm{PM}_{10}$ concentration in Vilnius district was low throughout 2016, but there was the same, as in 2019-2020, a sudden increase in the winter 
season was observed due to the cumulative effect of house heating, energetic objects and transport and because of an adverse effect on the dispersion of pollutant meteorological conditions (prevailing calm conditions).

Between 2005 and 2019, the emissions of particulate matter declined considerably by around $29 \%$ in the EU-27 Member States. The required decrease is significant for a number of countries, including 10 of those demanding reductions in more than 30\% (European Environment Agency, 2021).

The concentrations of air pollutants in the residential areas studied within the January-February period also increased compared to the values of the autumn season. However, a significantly larger change was monitored in the blocks of private households lacking district heating. In spring, the heating season continued along with the conducted research, but in the majority of points temperature was twice as high (average of $6^{\circ} \mathrm{C}$ ) as that in winter (average 3 of ${ }^{\circ} \mathrm{C}$ ). Pollution from road transport peaked at several measurement points, but the concentration of particulate matter in residential areas increased the most thus making $42-53 \mu \mathrm{g} / \mathrm{m}^{3}$. It is assumed that an increase in pollution following the winter season contributed to the current pollution due to the level of pollutants generated by private houses and centralized boilers because of the ongoing heating season. Traffic flows were noticed to be rising, which also might increase air pollution.

Variations in sulfur dioxide $\left(\mathrm{SO}_{2}\right)$ concentration are shown in Fig. 3 and Table 4. 
Table 4

Measured $\mathrm{SO}_{2}$ concentration (in $\mathrm{\mu g} / \mathrm{m}^{3}$ ) in the recreation territory and areas close to intense transport streets

\begin{tabular}{|c|c|c|c|c|c|c|}
\hline \multicolumn{7}{|l|}{ Recreation territory } \\
\hline Season/Point & [07] & & {$[012]$} & & [016] & \\
\hline Winter & 2.8 & & 3.8 & & 1.9 & \\
\hline Spring & 2.2 & & 2.1 & & 3.0 & \\
\hline Summer & 3.6 & & 4.4 & & 1.9 & \\
\hline Autumn & 1.8 & & 0.7 & & 0.3 & \\
\hline \multicolumn{7}{|l|}{ Areas close to intense transport streets } \\
\hline Season/Point & [01] & [05] & [06] & [010] & [011] & [015] \\
\hline Winter & 3.1 & 6.2 & 2.4 & 5.1 & 5.6 & 0.59 \\
\hline Spring & 2.2 & 3.4 & 4.5 & 1.7 & 3.6 & 3.6 \\
\hline Summer & 2.0 & 1.7 & 5.4 & 6.2 & 4.6 & 0.9 \\
\hline Autumn & 2.2 & 2.7 & 2.8 & 2.0 & 2.4 & 2.9 \\
\hline Annual limit value for the protection of human health & 20.0 & & & & & \\
\hline
\end{tabular}

The detection of sulfur dioxide may signal the sources of heavy hydrocarbon combustion, high emissions from high-traffic vehicles and pollution from industrial sites. The estimated level of the concentration of the above introduced pollutant was found to be low, for instance, the average $\mathrm{SO}_{2}$ concentration varied in different seasons of the year and made $2.1 \mu \mathrm{g} / \mathrm{m}^{3}$ in autumn, $3.3 \mu \mathrm{g} / \mathrm{m}^{3}$ in winter, $3.1 \mu \mathrm{g} / \mathrm{m}^{3}$ in spring and $3.1 \mu \mathrm{g} / \mathrm{m}^{3}$ in summer. The maximum $\mathrm{SO}_{2}$ concentration level took in summer due to intense traffic flow comparing to other seasons, the cite 014 is located near to intense interurban road. This level is decresing and the concentration decreased triple from 2016 till 2020. The average concentration of all seasons is $2.9 \mu \mathrm{g} / \mathrm{m}^{3}$. The above mentioned pollutant was higher than those set in recreation territories or in the living environment at almost all measurement points related to heavy traffic flow (measurement points $5,6,10$ and 11). $\mathrm{SO}_{2}$ concentration was found to be highest in winter and especially summer. The carried out research showed that ambient temperature $\left(21-28^{\circ} \mathrm{C}\right)$ exceeded the normal one at these points during summertime and wind speed was constant at around $2.5-3 \mathrm{~m} / \mathrm{s}$. One of the largest traffic flows was recorded particularly at these points, and the most intense one was set at measurement point 10 where 66 vehicles had passed within a period of 1 hour. Measurement point 13 is accepted as an exception representing the residential area, however, in the case of extremely intensive traffic flow (180 pcs / hour), $\mathrm{SO}_{2}$ concentration was slightly higher than the average of all studies, and the highest one was estimated during the spring season $\left(3.9 \mu \mathrm{g} / \mathrm{m}^{3}\right)$. 
Ambient $\mathrm{SO}_{2}$ concentration varied from 0.3 to $18.0 \mu \mathrm{g} / \mathrm{m}^{3}$, an average was $3.4 \mu \mathrm{g} / \mathrm{m}^{3}$ in 2016 in Vilnius district. The minimum value of $\mathrm{SO}_{2}$ concentration was equal to $0.3 \mu \mathrm{g} / \mathrm{m}^{3}$ (average winter value made $1.5 \mu \mathrm{g} / \mathrm{m}^{3}$ ) in March 2016 in contrast with that of $3.3 \mu \mathrm{g} / \mathrm{m}^{3}$ for the case in the 2019-2020 period. The maximum emission was equal to $18.0 \mu \mathrm{g} / \mathrm{m}^{3}$ (average summer value made $5.3 \mu \mathrm{g} / \mathrm{m}^{3}$ ) detected in June 2016 (for example, $3.1 \mu \mathrm{g} / \mathrm{m}^{3}$ for the period 2019-2020).

In line to the data provided by the European Environment Agency, $27.7 \mathrm{kt}$ (EEA33) and $25.6 \mathrm{kt}$ (EU28) of sulfur dioxide were emitted in the European Union in 1990, whereas in 2011 the index identifying the remaining part of pollutants made $26.5 \%$ and $17.9 \%$ respectively. In 2020 , conforming to the Gothenburg Protocol, the annual target value was hardly realized due to its index equal to 12,5 and the EU28 index making 32.7. $\mathrm{SO}_{2}$ emissions declined in the EU27 Member States by $76 \%$ for the period from 2005 to 2019.

Higher $\mathrm{SO}_{2}$ concentration was observed at an ambient temperature above $28^{\circ} \mathrm{C}$. In cold weather (winter) but at a relatively low air temperature of around $2^{\circ} \mathrm{C}$, an increase can be observed at the measurement points in the areas close to the residential blocks due to the increased use of liquid fuel (diesel) for heating.

Variations in nitrogen dioxide $\left(\mathrm{NO}_{2}\right)$ concentration are shown in Fig. 4.

Nitrogen oxides act as one of the components in emissions, particularly during the high-temperature combustion of gaseous fuels. The improper handling and storage of organic waste in open air due to the activity of microorganisms during the decay process may increase the concentration of nitrogen oxides and other pollutants as well as cause unpleasant odours. Figure 4 shows $\mathrm{NO}_{2}$ concentration exceeding the value of $30.0 \mu \mathrm{g} / \mathrm{m}^{3}$ established for vegetation protection and found in $50 \%$ of all measurement points during the summer season when the average air temperature made $23.2^{\circ} \mathrm{C}$ at a variable wind speed of 2.5-2.7 m/s. A significant increase in $\mathrm{NO}_{2}$ concentration was observed at the measurement points near the motorways. When the traffic is more than 60 vehicles/hour, the concentration of nitrogen dioxides increased more than 1.4 times. Although concentration was also high in spring, however, it was 1.5 times lower than that in summer. The level of pollutant concentration in residential areas changed insignificantly both in summer and the rest of the seasons.

The minimum value of $\mathrm{NO}_{2}$ concentration in 2016 was found to be equal to $3.5 \mu \mathrm{g} / \mathrm{m}^{3}$ in March 2016 $\left(5.7 \mu \mathrm{g} / \mathrm{m}^{3}\right.$ in September 2019), and an average of winter 2016 made $9.6 \mu \mathrm{g} / \mathrm{m}^{3}\left(16.6 \mu \mathrm{g} / \mathrm{m}^{3}\right.$ in 2020). The recorded maximum value of $\mathrm{NO}_{2}$ equalled $19.0 \mu \mathrm{g} / \mathrm{m}^{3}$ (average summer value reached $13.7 \mu \mathrm{g} / \mathrm{m} 3$ ) in June 2016 and was 3.2 times lower than that in summer 2020.

The potential sources of nitrogen dioxide pollutants are slightly different from those of particulate matter or sulfur dioxide, and therefore no overall correlation was found, except that pollution was higher in spring and summer rather than in other seasons. The formation and accumulation of pollutants close to 
roads are determined by the specific relief of Vilnius district. The Medininkai Upland rises in the east of Vilnius District, the Dainava Lowland occupies the southeast and the Aukstaiciai Upland is in the northwest. Thus, the pollutants generated in the south-eastern part of the city accumulate directly in this area, and those transferred from other areas may accumulate in this zone and do not move further. Neris, Vilnele and Voke valleys are located in the central and eastern part of Vilnius district, create a greater mix of traffic flows in this zone, and therefore the spontaneous clean-up of the environment is more intensive than elsewhere. Meanwhile, the second zone of pollutant accumulation is the northern part of Vilnius district characteristic of lowlands. The lowest measurement point of Vilnius district is at the western border of the district in the Neris Valley.

In 1990, the European Union generated $18.3 \mathrm{kt}$ (EEA33) and $17.3 \mathrm{kt}$ (EU28) of nitrogen oxides, while in 2011 the remaining quantities (indices) accounted for $56 \%$ and $51 \%$ respectively. In 2020, Gothenburg Target Value Index was equal to 38.8 and was failed to be reached under the EU28 index of 52.4.

EEA33 $\mathrm{NO}_{\mathrm{x}}$ emissions decreased up to $40 \%$ in 1990-2011 period. Decreased $\mathrm{NO}_{\mathrm{x}}$ emissions were declared for the bigger part of countries, especially in road transport sector (up to $47 \%$ by total) and energetics $(27 \%)$.

The initial chemical compound that forms during combustion and other processes and causes the formation of climate change greenhouse gases $\left(\mathrm{CO}_{2}\right)$ is presented by carbon monoxide (CO) the variations of the concentration of which are given in Table 5. 
Table 5

Carbon monoxide (CO) concentration in the ambient air of Vilnius district: $\left(\mathrm{mg} / \mathrm{m}^{3}\right):$ a - residential territory; $b$ - recreation territory; $c$ - areas close to intense transport streets

\begin{tabular}{|c|c|c|c|c|c|c|c|}
\hline \multicolumn{8}{|l|}{ Residential territory } \\
\hline Season/Point & [02] & [03] & [04] & [08] & [09] & [013] & [014] \\
\hline Winter & 3.0 & 2.8 & 0.4 & 0.2 & 0.3 & 0.6 & 0.5 \\
\hline Spring & 0.5 & 0.2 & 0.3 & 2.1 & 0.2 & 0.2 & 0.2 \\
\hline Summer & 0.9 & 0.5 & 1.0 & 0.7 & 0.8 & 0.2 & 0.1 \\
\hline Autumn & 0.2 & 0.1 & 1.2 & 0.1 & 0.5 & 0.2 & 0.5 \\
\hline \multicolumn{8}{|l|}{ recreation territory } \\
\hline Season/Point & [07] & & [012] & & & [016] & \\
\hline Winter & 0.3 & & 0.4 & & & 0.3 & \\
\hline Spring & 0.4 & & 0.2 & & & 0.4 & \\
\hline Summer & 0.9 & & 0.8 & & & 0.2 & \\
\hline Autumn & 0.1 & & 2.6 & & & 0.2 & \\
\hline \multicolumn{8}{|l|}{ Areas close to intense transport streets } \\
\hline Season/Point & [01] & [05] & [06] & [010] & [011] & [015] & \\
\hline Winter & 0.4 & 0.4 & 0.3 & 0.3 & 2.2 & 0.7 & \\
\hline Spring & 0.2 & 0.2 & 0.2 & 0.4 & 0.4 & 0.5 & \\
\hline Summer & 0.5 & 0.2 & 1.3 & 0.8 & 0.1 & 0.3 & \\
\hline Autumn & 0.1 & 0.6 & 0.03 & 0.1 & 0.4 & 0.6 & \\
\hline $\begin{array}{l}\text { Annual limit value for the protection of } \\
\text { human health }\end{array}$ & 10.0 & & & & & & \\
\hline
\end{tabular}

Assuming that carbon monoxide is emitted from the anthropogenic sources of pollution, a particularly high concentration of $\mathrm{CO}$ is observed during the winter season. Evidence has been obtained at measurement points 2, 3 and 11 belonging to household and heavy traffic areas. A similar trend was noticed for $\mathrm{SO}_{2}$ concentration. The meteorological conditions of the carried out research included the wind of 2-2.5 m/s under the extremely low or insignificant dispersion of pollutants. Slightly lower CO concentration was found at one of the measurement points of recreation territories and household areas during autumn and spring seasons. Traffic flows recorded in the household area reached up to 60 vehicles per hour. An increase in $\mathrm{CO}$ concentration may frequently correlate with $\mathrm{PM}_{10}$ concentration values, however, this dependence was found to occur only in autumn. None of the received $\mathrm{PM}_{10}$ values 
was close to the applicable annual limit value of $40.0 \mu \mathrm{g} / \mathrm{m}^{3}$, which indcated that the resulting pollution was insignificant.

The values of $\mathrm{CO}$ concentration varied from 0.7 to $2.1 \mathrm{mg} / \mathrm{m}^{3}$ under the average value equal to 1.3 $\mathrm{mg} / \mathrm{m}^{3}$ and the minimum value of $0.7 \mathrm{mg} / \mathrm{m}^{3}$ (average winter value made $1.2 \mathrm{mg} / \mathrm{m}^{3}$ under a value of $0.8 \mathrm{mg} / \mathrm{m}^{3}$ in winter 2020) in March 2016. The maximum value of $2.1 \mathrm{mg} / \mathrm{m}^{3}$ (average summer value reached $1.36 \mathrm{mg} / \mathrm{m}^{3}$ under a value of $1.1 \mathrm{mg} / \mathrm{m}^{3}$ in summer 2020) was detected in June 2016.

Freight $\mathrm{CO}_{2}$ emissions are expected to rise $22 \%$ from 2015 to 2050 . Return to 'normal' after the pandemic will miss $\mathrm{CO}_{2}$ reduction targets. With increased ambition, a $72 \%$ cut in freight $\mathrm{CO}_{2}$ is possible over the next three decades.

The estimated freight transport emissions under the current policies making 105 by 2030 and 120 by 2050 are current policies (recover scenario) comparing with 2015 (under the index equal to 100), those making 85 by 2030 and 35 by 2050 are ambitious policies (Reshape scenario) and 65 by 2030 and 30 by 2050 are ambitious policies, leveraged recovery (Reshape + scenario).

Road transport is responsible for $65 \%$ of freight emissions. The majority of emissions come from road and urban logistics, critical front to reduce emissions. Its share will increase in all scenarios by 2050 . The total $\mathrm{CO}_{2}$ emissions from freight transport under the current policies will be equal to around $2500 \mathrm{Mt} \mathrm{CO}_{2}$ from the road (including urban logistics) and $600 \mathrm{Mt} \mathrm{CO}_{2}$ from the Sea region by 2050 .

Tropospheric ozone is one of the main agents which impacts on the breathing system and causes more deseases such as asthma, bronchitis etc. (Kahle et al., 2015).

Ozone concentration increases significantly when exposed to solar radiation and immediately after lightning discharge. Seasonal variations in the concentration determined by studies are provided in Table 6. 
Table 6

Ozone $\left(\mathrm{O}_{3}\right)$ concentration $\left(\mu \mathrm{g} / \mathrm{m}^{3}\right)$ in the ambient air of Vilnius district: a - residential territory; b recreation territory; $\mathrm{c}$ - areas close to intense transport streets

\begin{tabular}{|lllllllll|}
\hline Residential territory & & & & & & & \\
\hline Season/Point & {$[02]$} & {$[03]$} & {$[04]$} & {$[08]$} & {$[09]$} & {$[013]$} & [014] \\
\hline Winter & 50.4 & 47.5 & 55.4 & 35.8 & 26.4 & 51.8 & 19.4 \\
\hline Spring & 68.6 & 67.8 & 98.4 & 63.1 & 58.8 & 76.5 & 79.2 \\
\hline Summer & 45.4 & 61.6 & 44.1 & 29.5 & 26.4 & 58.7 & 51.8 \\
\hline Autumn & 63.0 & 30.0 & 51.0 & 87.0 & 52.0 & 71.0 & 64.0 \\
\hline recreation territory & & & & & & & \\
\hline Season/Point & {$[07]$} & & {$[012]$} & & & {$[016]$} & \\
\hline Winter & 24.8 & & 35.0 & & & 22.5 & \\
\hline Spring & 69.6 & & 98.9 & & & 70.1 & \\
\hline Summer & 43.2 & & 47.0 & & & 41.4 & \\
\hline Autumn & 60.0 & & 44.0 & & & 72.0 & \\
\hline Areas close to intense transport streets & & & & & & & \\
\hline Season/Point & {$[01]$} & {$[05]$} & {$[06]$} & {$[010]$} & {$[011]$} & {$[015]$} & \\
\hline Winter & 37.5 & 52.6 & 21.0 & 61.3 & 54.7 & 46.0 & \\
\hline Spring & 75.8 & 78.7 & 69.8 & 90.2 & 63.1 & 61.9 & \\
\hline Summer & 38.9 & 45.6 & 31.0 & 49.5 & 63.4 & 45.4 & \\
\hline Autumn & 65.0 & 30.0 & 43.0 & 101.0 & 55.0 & 51.0 & \\
\hline Annual limit value for the protection of & 120.0 & & & & & & \\
human health & & & & & & & \\
\hline
\end{tabular}

$\mathrm{O}_{3}$ concentration compared to the established limit value $\left(120 \mu \mathrm{g} / \mathrm{m}^{3}\right)$ was found to be lower but close to the set limit. No significant differences between different periods were observed, but the values were slightly higher in spring and autumn. Similar variations in the concentrations of pollutants $\mathrm{PM}_{10}$ and $\mathrm{O}_{3}$ at measurement points 4, 6, 10 and 12 were detected in spring. Irrespective of the type of the zone, ozone concentration remained similar at these points and no significant effects of meteorological conditions were noticed.

$\mathrm{O}_{3}$ concentration varied from 43.5 to $110.9 \mu \mathrm{g} / \mathrm{m}^{3}$ with an average value of $71.9 \mu \mathrm{g} / \mathrm{m}^{3}$ during the first phase (in 2016) and was 1.52 times lower than that during the second phase in 2019-2020. The 
minimum value of $\mathrm{O}_{3}$ concentration was recorded to be $43.5 \mu \mathrm{g} / \mathrm{m}^{3}\left(19.4 \mu \mathrm{g} / \mathrm{m}^{3}\right.$ in 2020). The maximum value of $110.9 \mu \mathrm{g} / \mathrm{m}^{3}$ (average winter value made $67.6 \mu \mathrm{g} / \mathrm{m}^{3}$ ) was detected in March 2016, and the average summer value made $76.1 \mu \mathrm{g} / \mathrm{m}^{3}$, which was 1.19 times lower comparing with the period of 2019-2020.

The values of one of the VOC - benzene were found to be slightly above the detection limit and ranged from 0.4 to $1.5 \mu \mathrm{g} / \mathrm{m}^{3}$ at all measurement points. The highest values were set during the winter season (average of $1.1 \mu \mathrm{g} / \mathrm{m}^{3}$ ) and were on average 1.4, 2.7 and 2.1 times lower in the following seasons. The average concentration of benzene in different seasons of the year was found to be equal to $0.5 \mu \mathrm{g} / \mathrm{m}^{3}$ in autumn, $1.1 \mu \mathrm{g} / \mathrm{m}^{3}$ - in winter, $0.8 \mu \mathrm{g} / \mathrm{m}^{3}$ - in spring and $0.4 \mu \mathrm{g} / \mathrm{m}^{3}-$ in summer. The average concentration of benzene makes $0.7 \mu \mathrm{g} / \mathrm{m}^{3}$ in all seasons.

Toluene concentration slightly differed at measurement points 3, 5, 7 and 13 in the summer season and at measurement points $4,5,7,8$ in autumn. The maximum value of $28.1 \mu \mathrm{g} / \mathrm{m}^{3}$ was set at measurement point 13 in summer and $27.9 \mu \mathrm{g} / \mathrm{m}^{3}$ at measurement point 5 in autumn. These points are located close to larger transport hubs, and therefore a possible source of pollution is the vapour of unburned liquid fuel. These periods were dominated by a higher than normal temperature of $20-25^{\circ} \mathrm{C}$, which further intensified pollutant emissions. The range of the T/B ratio measured for the investigated area of Vilnius district fluctuated between 0.5 and 1.4 in 2016, which is a typical value of the rural and particularly of the urban area. Benzene concentration in Vilnius district varied from 0.5 to $3.2 \mu \mathrm{g} / \mathrm{m}^{3}$, and the average value made $1.5 \mu \mathrm{g} / \mathrm{m}^{3}$. The minimum value of benzene concentration was recorded to be $0.5 \mu \mathrm{g} / \mathrm{m}^{3}$ in June 2016 (average value of the summer period made $0.6 \mu \mathrm{g} / \mathrm{m}^{3}$ ).

A similar situation was observed investigating ethylbenzene and $\mathrm{m}-, \mathrm{p}$ - and o-xylene. The concentrations of all four pollutants were largest in autumn and the highest one was established at measurement point 5 where the value of ethylbenzene was $36.3 \mu \mathrm{g} / \mathrm{m}^{3}$, that of $\mathrm{m}$ - and p-xylenes $-37.5 \mu \mathrm{g} / \mathrm{m}^{3}$ and that of oxylenes $-12.0 \mu \mathrm{g} / \mathrm{m}^{3}$. The determined average concentration of ethylbenzene in different seasons of the year equalled $4.8 \mu \mathrm{g} / \mathrm{m}^{3}$ in autumn, $0.7 \mu \mathrm{g} / \mathrm{m}^{3}$ in winter, $0.8 \mu \mathrm{g} / \mathrm{m}^{3}$ in spring and $0.6 \mu \mathrm{g} / \mathrm{m}^{3}$ in summer. Ethylbenzene concentration in Vilnius district varied from $<0.5$ to $0.6 \mu \mathrm{g} / \mathrm{m}^{3}$, and the average value was equal to $0.4 \mu \mathrm{g} / \mathrm{m}^{3}$. The minimum value of ethylbenzene concentration made $<0.5 \mu \mathrm{g} / \mathrm{m}^{3}$ and was recorded in June 2016 (average value of the summer period made $0.3 \mu \mathrm{g} / \mathrm{m}^{3}$ ).

The average concentration of $\mathrm{m}$ - and $\mathrm{p}$-xylenes was equal to $2.0 \mu \mathrm{g} / \mathrm{m}^{3}$ in all seasons. The determined average concentration of $\mathrm{m}$ - and $\mathrm{p}$-xylenes in different seasons of the year made $5.03 \mu \mathrm{g} / \mathrm{m}^{3}$ in autumn, $0.8 \mu \mathrm{g} / \mathrm{m}^{3}$ in winter, $0.9 \mu \mathrm{g} / \mathrm{m}^{3}$ in spring and $1.2 \mu \mathrm{g} / \mathrm{m}^{3}$ in summer. The average annual concentration of o-xylenes was 2.29 times lower than that of $\mathrm{m}$ - and $\mathrm{p}$-xylenes, and the ratio varied from 1.44 to 2.91 times in individual seasons. Xylene concentration in Vilnius district fluctuated from 0.5 to $1.1 \mu \mathrm{g} / \mathrm{m}^{3}$ in 2016 , and the average value equalled $0.7 \mu \mathrm{g} / \mathrm{m}^{3}$. The recorded minimum value of xylene concentration was equal to $0.5 \mu \mathrm{g} / \mathrm{m}^{3}$ (average value of the summer period made $0.6 \mu \mathrm{g} / \mathrm{m}^{3}$ ). The maximum value of xylene 
made $1.1 \mu \mathrm{g} / \mathrm{m}^{3}$ (average value of the winter period reached $0.8 \mu \mathrm{g} / \mathrm{m}^{3}$ ) and was detected in winter 2016 . Xylene concentration in the ambient air of Vilnius district ranged from 0.5 to $1.0 \mu \mathrm{g} / \mathrm{m}^{3}$ during winter and summer seasons.

Particular attention is paid to the environmental monitoring of industrial enterprises located in the city or suburbs. The main objects of pollution with ammonia in Vilnius district include hen houses and technological buildings storing and processing chicken manure as well as handling organic and inorganic farm waste. The average daily ammonia concentration determined for each season is shown in Fig. 5.

The concentration of this pollutant in the air ranged from 3.1 to $10.9 \mu \mathrm{g} / \mathrm{m}^{3}$ and was $3.69-12.9$ times lower than the daily limit value $\left(40.0 \mu \mathrm{g} / \mathrm{m}^{3}\right)$. Although the area of this economic activity is only $6 \mathrm{~km}$ away from the city limits, however, it is surrounded by the area of residential blocks, apartment and public buildings. Thus, the urbanization level of a district-type town is growing rapidly and is expected to develop in the future. Ammonia concentration varied steadily in different seasons of the year and was found to be higher in a warmer season (summer) thus reaching $10.9 \mu \mathrm{g} / \mathrm{m}^{3}$. The average annual ammonia concentration is equal to $6.2 \mu \mathrm{g} / \mathrm{m}^{3}$. At a temperature closer to $0^{\circ} \mathrm{C}$, emissions decrease on average by more than 2.5 times, and such pattern was identified during winter and spring seasons when temperature ranged between -2 and $2^{\circ} \mathrm{C}$. The conducted research demonstrated the prevailing moderate wind speeds of 2.4-3.5 m/s. The research was carried out at the measurement points just downwind of the pollution source at equal distances $(750-850 \mathrm{~m})$. It is assumed that the established concentration was highest and decreased steadily in other directions.

Pearson criterion was applied for the statistical analysis of the obtained research results when looking for a correlation between two pollutant values at the measurement points. The coefficient of the received indicator shows the strength of the relationship between variations in two parameters, and the preliminary relationship is evaluated in line to the given scale: correlation is missing when the value of the correlation coefficient is equal to 0 ; correlation is very weak when the value of the correlation coefficient falls in the range of $[-0.2 ; 0)$ or $(0 ; 0.2]$; correlation is weak when parameters are equal to $[-0.4 ;-0.2)$ or $(0.2$; $0.4]$; correlation is medium under parameters $[-0.7 ;-0.4)$ or $(0.4 ; 0.7]$; correlation is strong under parameters $[-0.9 ;-0.7)$ or $(0.7 ; 0.9]$; correlation is very strong under parameters $[-1.0 ;-0.9)$ or $(0.9 ; 1.0]$; linear relationship equals -1 or 1 .

Among all analysed cases, the strongest correlation is observed between the concentrations of $\mathrm{PM}_{10}$ and $\mathrm{O}_{3}$ in spring under the Pearson coefficient equal to 0.64. A slightly lower correlation is noticed between the concentrations of $\mathrm{CO}$ and $\mathrm{O}_{3}$ in summer, $\mathrm{PM}_{10}$ and $\mathrm{NO}_{2}$ in spring, $\mathrm{PM}_{10}$ and $\mathrm{CO}$ in summer, $\mathrm{PM}_{10}$ and $\mathrm{O}_{3}$ in winter and $\mathrm{SO}_{2}$ and $\mathrm{NO}_{2}$ in autumn under the Pearson coefficient equal to $0.51-0.57$. A moderate to weak correlation was found in most cases, with the concentrations of $\mathrm{PM}_{10}$ and $\mathrm{SO}_{2}$ correlating the most (except for the summer season when correlation was very weak) under the Pearson coefficient fluctuating 
from -0.402 to -0.476 in all cases. The correlation between $\mathrm{SO}_{2}$ and $\mathrm{NO}_{2}$ was moderate in autumn only but weak during other seasons.

A very weak or weak correlation was discovered between the concentrations of $\mathrm{PM}_{10}$ and $\mathrm{CO}$ and $\mathrm{CO}$ and $\mathrm{O}_{3}$, with the exception of comparing the results obtained during the summer season and the concentrations of $\mathrm{SO}_{2}$ and $\mathrm{CO}$. In the latter case, the exception is represented by the results obtained during the autumn season. The correlation between $\mathrm{SO}_{2}$ and $\mathrm{O}_{3}$ as well as between $\mathrm{NO}_{2}$ and $\mathrm{O}_{3}$ was very weak throughout all seasons with the weakest correlation seen between the concentrations of $\mathrm{NO}_{2}$ and $\mathrm{CO}$ at the measurement points.

In line to EU28 Gothenburg target, $\mathrm{SO}_{2}$ limits make 12.5 and those of $\mathrm{NO}_{2}-38.8$. Similar measurements were carried out in other Lithuanian cities, Kaunas and Vilnius. The findings showed that $\mathrm{NO}_{2}$ concentration in the biggest cities of Lithuania ranged from 11.4 to $26.3 \mu \mathrm{g} / \mathrm{m}^{3}$ in Kaunas (Laurinavičienè, 2011) and from 16.9 to $39.2 \mu \mathrm{g} / \mathrm{m}^{3}$ in Vilnius (Šerevičienė \& Paliulis, 2011). Other researchers recorded the following results of $\mathrm{NO}_{2}$ concentration in ambient air: Vietnam - 17.9-65.9 $\mu \mathrm{g} / \mathrm{m}^{3}$ (Hien et al., 2014), Kuwait - 12.8-29.0 $\mu \mathrm{g} / \mathrm{m}^{3}$ (Al-Awadhi, 2014), Cuba - 4.8-21.4 $\mu \mathrm{g} / \mathrm{m}^{3}$ (Alejo et al., 2013), Canada - 0.3-1.52 $\mu \mathrm{g} / \mathrm{m}^{3}$ (Gibson et al., 2013); China - 1.1-45.0 $\mu \mathrm{g} / \mathrm{m}^{3}$ (Meng et al., 2010), United Kingdom - 24.5-43.3 $\mu \mathrm{g} / \mathrm{m}^{3}$ (Stevenson et al., 2001); Turkey - 14.0-29.7 $\mu \mathrm{g} / \mathrm{m}^{3}$ (Akdemir, 2014); Brazil - 49.0-63.0 $\mu \mathrm{g} / \mathrm{m}^{3}$ (da Silva et al., 2006), Pakistan - $82.8 \mu \mathrm{g} / \mathrm{m}^{3}$ (Ahmad \& Aziz, 2013), Spain $18.1-29.4 \mu \mathrm{g} / \mathrm{m}^{3}$ (Lozano García et al., 2010). Thus, $\mathrm{NO}_{2}$ concentration in Lithuania is similar to that of other countries.

More researchers observed $\mathrm{SO}_{2}$ concentration in ambient air and identified the following situation: Vietnam - 11.7-47.4 $\mu \mathrm{g} / \mathrm{m}^{3}$ (Hien et al., 2014), Kuwait - 6.5-15.4 $\mu \mathrm{g} / \mathrm{m}^{3}$ (Al-Awadhi, 2014), Cuba $2.1-10.5 \mu \mathrm{g} / \mathrm{m}^{3}$ (Alejo et al., 2013), Canada $-0.6-0.6 \mu \mathrm{g} / \mathrm{m}^{3}$ (Gibson et al., 2013), China - 1.8-176.3 $\mu \mathrm{g} / \mathrm{m}^{3}$ (Meng et al., 2010), Malaysia and Indonesia $-1.7 \mu \mathrm{g} / \mathrm{m}^{3}$, East Asia $-5.0 \mu \mathrm{g} / \mathrm{m}^{3}$, China, Nepal $20.0 \mu \mathrm{g} / \mathrm{m}^{3}$ (Carmichael et al., 2003), Turkey - 8.0-21.0 $\mu \mathrm{g} / \mathrm{m}^{3}$ (Akdemir, 2014; Pekey \& Özaslan, 2013). Hence, $\mathrm{SO}_{2}$ concentration in Lithuania is lower than that of other countries. Conforming to the data provided by the Lithuanian Environmental Protection Agency, the concentrations of $\mathrm{SO}_{2}$ and $\mathrm{NO}_{2}$ in ambient air ranged up to $2.0 \mu \mathrm{g} / \mathrm{m}^{3}$ and $15.0 \mu \mathrm{g} / \mathrm{m}^{3}$ respectively.

Air pollution is expected to further decline in the coming years, however, only beyond 2030 slow progress is observed. At the end of 2013, the European Commission adopted a Clean Air Policy Package for Europe. The document proposed fully complying with the existing air quality legislation by 2030 and subsequently further improving air quality in Europe by 2030 (OECD, 2001). As a part of this package, the Commission presented the amended NEC Directive recommending new emission reduction national level for 2020 and 2030. The amendment establishes stricter national emission reduction commitments for four main air pollutants, including sulfur compounds (mainly sulfur dioxide), nitrogen oxides, nonmethane volatile organic compounds and ammonia. The limit values of the above introduced emissions 
apply to every country and to each pollutant from 2020 onwards. The fifth pollutant is fine particulate matter and is being regulated for the first time. The Protocol also sets emission reduction commitments for this pollutant.

Reducing emissions from energy facilities is one of the methods for mitigating climate change. To successfully achieve the goal, boilers are modernized by replacing combustion fuel with the one less polluting air (burnt fuel is most frequently replaced with gas) and installing air treatment equipment in energy facilities (usually for capturing particulate matter).

In order to develop infrastructure and improve transport in urban areas, a network of bypasses connecting the busiest roads from north-west to south-east and from south to north is being developed particularly fast. The employment of the circular communication model inevitably affects the above listed polluted areas thus posing additional engineering-technological challenges to avoid pollution problems. The installation of the main bypasses is often used in the artificially formed valleys (between two embankments). The resulting air pollutants remain at the road level and hardly spread over the embankments, whereas road construction is selected in the areas having the lowest potential for urbanization in the future but closer to the tertiary roads of minor importance to improve traffic.

\section{Conclusions}

- The average concentrations of $\mathrm{CO}, \mathrm{PM}_{10}$ and $\mathrm{NO}_{2}$ calculated in the areas close to intense transport streets during all investigated seasons were $0.5 \mathrm{mg} / \mathrm{m}^{3}, 18.3 \mu \mathrm{g} / \mathrm{m}^{3}$ and $23.5 \mu \mathrm{g} / \mathrm{m}^{3}$ respectively, which was more than $8 \%$ higher than the average level in the ambient air of Vilnius district.

- CO concentration in the ambient air of Vilnius district ranged from 0.03 to $3.0 \mathrm{mg} / \mathrm{m}^{3}$ during the investigated period, $\mathrm{O}_{3}$ concentration varied from 19.4 to $101.0 \mu \mathrm{g} / \mathrm{m}^{3}$ and $\mathrm{NH}_{3}$ concentration fluctuated from 3.1 to $10.9 \mu \mathrm{g} / \mathrm{m}^{3}$.

- $\mathrm{PM}_{10}$ concentration in the ambient air of Vilnius district ranged from 1.4 to $53.4 \mu \mathrm{g} / \mathrm{m}^{3}$ during the investigated period and exceeded the annual limit value $\left(40.0 \mu \mathrm{g} / \mathrm{m}^{3}\right)$ set by European Union Council Directive 2008/50/EC in the areas close to intense transport streets.

- During the investigated period, the concentrations of BTEX (benzene, toluene, ethylbenzene, o-xylene and $m, p$-xylenes) in the ambient air of Vilnius district were higher than the limit of ethylbenzene more than 1.5 times and equalled $36.3 \mu \mathrm{g} / \mathrm{m}^{3}$ at one of the measurement points located close to intense transport streets. Other concentrations did not exceed the established limit values and the highest values were $1.5 ; 28.1 ; 8.0 ; 12.0$ and $37.5 \mu \mathrm{g} / \mathrm{m}^{3}$ respectively.

- During the investigated period, $\mathrm{NO}_{2}$ concentration in the ambient air of Vilnius district ranged from 5.7 to $61.6 \mu \mathrm{g} / \mathrm{m}^{3}$ and that of $\mathrm{SO}_{2}$ fluctuated from 0.3 to $6.3 \mu \mathrm{g} / \mathrm{m}^{3}$. Air pollution caused by the above mentioned pollutants did not exceed the limit values set by Gothenburg target and European Union Council Directive 2008/50/EC. 
- The average concentration of the selected pollutants determined during the investigated seasons take a decreasing order: spring $>$ winter $>$ summer $>$ autumn.

\section{Declarations}

Ethical Approval: Not applicable

Consent to Participate: Not applicable

Consent to Publish: Not applicable

Authors Contributions: Conceptualization, A.C. and D.P.; methodology, A.C. and D.P.; software, A.C. and D.P.; validation, A.C. and D.P.; formal analysis, A.C.; investigation, A.C., D.P. and J.B.; data curation, A.C., D.P. and J.B.; writing-original draft preparation, A.C., D.P. and J.B.; writing-review and editing, A.C.; visualization, A.C.; supervision, T.J.; project administration, A.C.; funding acquisition, T.J. All authors have read and agreed to the published version of the manuscript.

Funding: The authors declare that no funds, grants, or other support were received during the preparation of this manuscript.

Competing Interests: Financial interests: All Authors declare they have no financial interests.

Availability of data and materials: Not applicable

\section{References}

1. Adema EH, Heeres P, Rahayuningsih HA, Rineksa S (2012) The Determination of Ozone in Ambient Air with Free Hanging Filters as Passive Samplers. Water Air Soil Pollut 223(9):5719-5725. https://doi.org/10.1007/s11270-012-1309-z

2. Agrawal G, Mohan D, Rahman H (2021) Ambient air pollution in selected small cities in India: Observed trends and future challenges. IATSS Res. https://doi.org/10.1016/j.iatssr.2021.03.004

3. Ahmad SS, Aziz N (2013) Spatial and temporal analysis of ground level ozone and nitrogen dioxide concentration across the twin cities of Pakistan. Environ Monit Assess 185(4):3133-3147. https://doi.org/10.1007/s10661-012-2778-7

4. Akdemir A (2014) The Measurement of Ambient Concentration of Sulfur Dioxide and Nitrogen Dioxide with Passive Samplers and Pollution Mapping in Samsun, Turkey. Journal of Earth Science \& Climatic Change, 05. https://doi.org/10.4172/2157-7617.1000177

5. Al-Awadhi J (2014) Measurement of Air Pollution in Kuwait City Using Passive Samplers. Atmospheric and Climate Sciences 04:253-271. https://doi.org/10.4236/acs.2014.42028 
6. Alejo D, Morales MC, de la Torre JB, Grau R, Bencs L, Van Grieken R, Van Espen P, Sosa D, Nuñez V (2013) Seasonal trends of atmospheric nitrogen dioxide and sulfur dioxide over North Santa Clara, Cuba. Environ Monit Assess 185(7):6023-6033. https://doi.org/10.1007/s10661-012-3003-4

7. Carmichael GR, Ferm M, Thongboonchoo N, Woo J-H, Chan LY, Murano K, Viet PH, Mossberg C, Bala R, Boonjawat J, Upatum P, Mohan M, Adhikary SP, Shrestha AB, Pienaar JJ, Brunke EB, Chen T, Jie T, Guoan D, Bilici E (2003) Measurements of sulfur dioxide, ozone and ammonia concentrations in Asia, Africa, and South America using passive samplers. Atmos Environ 37(9):1293-1308. https://doi.org/https://doi.org/10.1016/S1352-2310(02)01009-9

8. Chen R, Huang W, Wong C-M, Wang Z, Thach TQ, Chen B, Kan H (2012) Short-term exposure to sulfur dioxide and daily mortality in 17 Chinese cities: the China air pollution and health effects study (CAPES). Environ Res 118:101-106. https://doi.org/10.1016/j.envres.2012.07.003

9. da Silva AS, Cardoso MR, Meliefste K, Brunekreef B (2006) Use of passive diffusion sampling method for defining NO2 concentrations gradient in São Paulo, Brazil. Environ Health 5(1):19. https://doi.org/10.1186/1476-069X-5-19

10. Davuliene L, Jasineviciene D, Garbariene I, Andriejauskiene J, Ulevicius V, Bycenkiene S (2021) Longterm air pollution trend analysis in the South-eastern Baltic region, 1981-2017. Atmos Res 247:105191. https://doi.org/10.1016/j.atmosres.2020.105191

11. Dovile L (2011) Distribution of Nitrogen Dioxide Concentration in Kaunas 2003-2007 Azoto dioksido koncentracijos pasiskirstymas Kaune 2003-2007. Environmental Research, Engineering and Management

12. European Environment Agency (2021) Emissions of the main air pollutants in Europe. Percentage Emission Reductions of Main Air Pollutants in 2019 Compared with 2005 Levels

13. Gibson MD, Heal MR, Li Z, Kuchta J, King GH, Hayes A, Lambert S (2013) The spatial and seasonal variation of nitrogen dioxide and sulfur dioxide in Cape Breton Highlands National Park, Canada, and the association with lichen abundance. Atmos Environ 64:303-311.

https://doi.org/https://doi.org/10.1016/j.atmosenv.2012.09.068

14. Hien PD, Hangartner M, Fabian S, Tan PM (2014) Concentrations of NO2, SO2, and benzene across Hanoi measured by passive diffusion samplers. Atmos Environ 88:66-73. https://doi.org/https://doi.org/10.1016/j.atmosenv.2014.01.036

15. lizuka A, Shirato S, Mizukoshi A, Noguchi M, Yamasaki A, Yanagisawa Y (2014) Region of Japan. Int J Environ Res Public Health 11:6844-6855. https://doi.org/10.3390/ijerph110706844. A Cluster Analysis of Constant Ambient Air Monitoring Data from the Kanto

16. Kahle JJ, Neas LM, Devlin RB, Case MW, Schmitt MT, Madden MC, Diaz-Sanchez D (2015) Interaction effects of temperature and ozone on lung function and markers of systemic inflammation, coagulation, and fibrinolysis: a crossover study of healthy young volunteers. Environ Health Perspect 123(4):310-316. https://doi.org/10.1289/ehp.1307986

17. Kerimray A, Baimatova N, Ibragimova OP, Bukenov B, Kenessov B, Plotitsyn P, Karaca F (2020) Assessing air quality changes in large cities during COVID-19 lockdowns: The impacts of traffic-free 
urban conditions in Almaty, Kazakhstan. Sci Total Environ 730:139179.

https://doi.org/10.1016/j.scitotenv.2020.139179

18. Król S, Zabiegała B, Namieśnik J (2012) Measurement of benzene concentration in urban air using passive sampling. Anal Bioanal Chem 403(4):1067-1082. https://doi.org/10.1007/s00216-0115578-y

19. Lozano García A, Usero J, Vanderlinden E, Raez J, Contreras J, Navarrete B, Bakouri E (2010) H. Optimization of the design of air quality monitoring networks and its application to NO2 and 03 in Seville, Spain 49 X Optimization of the design of air quality monitoring networks and its application to NO 2 and $O 3$ in Seville, Spain

20. Meng Z-Y, Xu X-B, Wang T, Zhang X-Y, Yu X-L, Wang S-F, Lin W-L, Chen Y-Z, Jiang Y-A, An X-Q (2010) Ambient sulfur dioxide, nitrogen dioxide, and ammonia at ten background and rural sites in China during 2007-2008. Atmos Environ 44(21):2625-2631.

https://doi.org/https://doi.org/10.1016/j.atmosenv.2010.04.008

21. Pekey B, Özaslan Ü (2013) Spatial Distribution of SO2, NO2, and 03 Concentrations in an Industrial City of Turkey Using a Passive Sampling Method. CLEAN - Soil Air Water, 41. https://doi.org/10.1002/clen.201200172

22. Pekey B, Yılmaz H (2011) The use of passive sampling to monitor spatial trends of volatile organic compounds (VOCs) at an industrial city of Turkey. Microchem J 97(2):213-219.

https://doi.org/https://doi.org/10.1016/j.microc.2010.09.006

23. Rushworth A, Lee D, Mitchell R (2014) A spatio-temporal model for estimating the long-term effects of air pollution on respiratory hospital admissions in Greater London. Spat Spatio-Temporal Epidemiol 10:29-38. https://doi.org/10.1016/J.SSTE.2014.05.001

24. Šerevičienè $V$, Baltrenas $P$, Baltrènaitè-Gedienė E, Marčiulaitienè E, Paliulis D (2014) Investigation of NO2 Behaviour in the Temperate Continental Climate Road Environment. Water Air and Soil Pollution 225:2173. https://doi.org/10.1007/s11270-014-2173-9

25. Šerevičienè V, Paliulis D (2011) Assessment of air quality using diffusive samplers and ADMS-Urban. Ekologija, 57. https://doi.org/10.6001/ekologija.v57i3.1918

26. Silva RA, West JJ, Zhang Y, Anenberg SC, Lamarque J-F, Shindell DT, Collins WJ, Dalsoren S, Faluvegi G, Folberth G, Horowitz LW, Nagashima T, Naik V, Rumbold S, Skeie R, Sudo K, Takemura T, Bergmann D, Cameron-Smith P, Zeng G (2013) Global premature mortality due to anthropogenic outdoor air pollution and the contribution of past climate change. Environ Res Lett 8(3):34005. https://doi.org/10.1088/1748-9326/8/3/034005

27. Słomińska M, Konieczka P, Namieśnik J (2014) The Fate of BTEX Compounds in Ambient Air. Crit Rev Environ Sci Technol 44(5):455-472. https://doi.org/10.1080/10643389.2012.728808

28. Stevenson K, Bush T, Mooney D (2001) Five years of nitrogen dioxide measurement with diffusion tube samplers at over 1000 sites in the UK. Atmos Environ 35(2):281-287. https://doi.org/https://doi.org/10.1016/S1352-2310(00)00171-0 
29. Wu J, Feng Z, Anwar S (2021) Assessing the pollution convergence across Chinese cities by considering ecological indicators: A continuous distribution dynamics approach. Ecol Ind 126:107552. https://doi.org/10.1016/j.ecolind.2021.107552

30. Xie Y, Dai H, Zhang Y, Wu Y, Hanaoka T, Masui T (2019) Comparison of health and economic impacts of PM2.5 and ozone pollution in China. Environ Int 130:104881. https://doi.org/10.1016/j.envint.2019.05.075

31. Zeng J, Bao R (2021) The impacts of human migration and city lockdowns on specific air pollutants during the COVID-19 outbreak: A spatial perspective. J Environ Manage 282:111907. https://doi.org/10.1016/j.jenvman.2020.111907

32. Zheng H, Kong S, Chen N, Yan Y, Liu D, Zhu B, Xu K, Cao W, Ding Q, Lan B, Zhang Z, Zheng M, Fan Z, Cheng Y, Zheng S, Yao L, Bai Y, Zhao T, Qi S (2020) Significant changes in the chemical compositions and sources of PM2.5 in Wuhan since the city lockdown as COVID-19. Sci Total Environ 739:140000. https://doi.org/10.1016/j.scitotenv.2020.140000

\section{Figures}




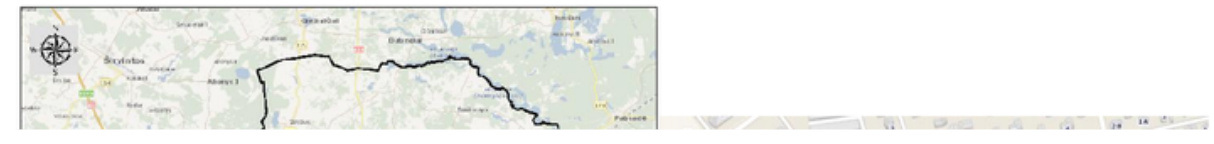

\section{Figure 1}

The research sites of air quality (a) and ammonia at a potential pollution source (b) in the area of Vilnius District Municipality in Eastern Europe scale (c) 


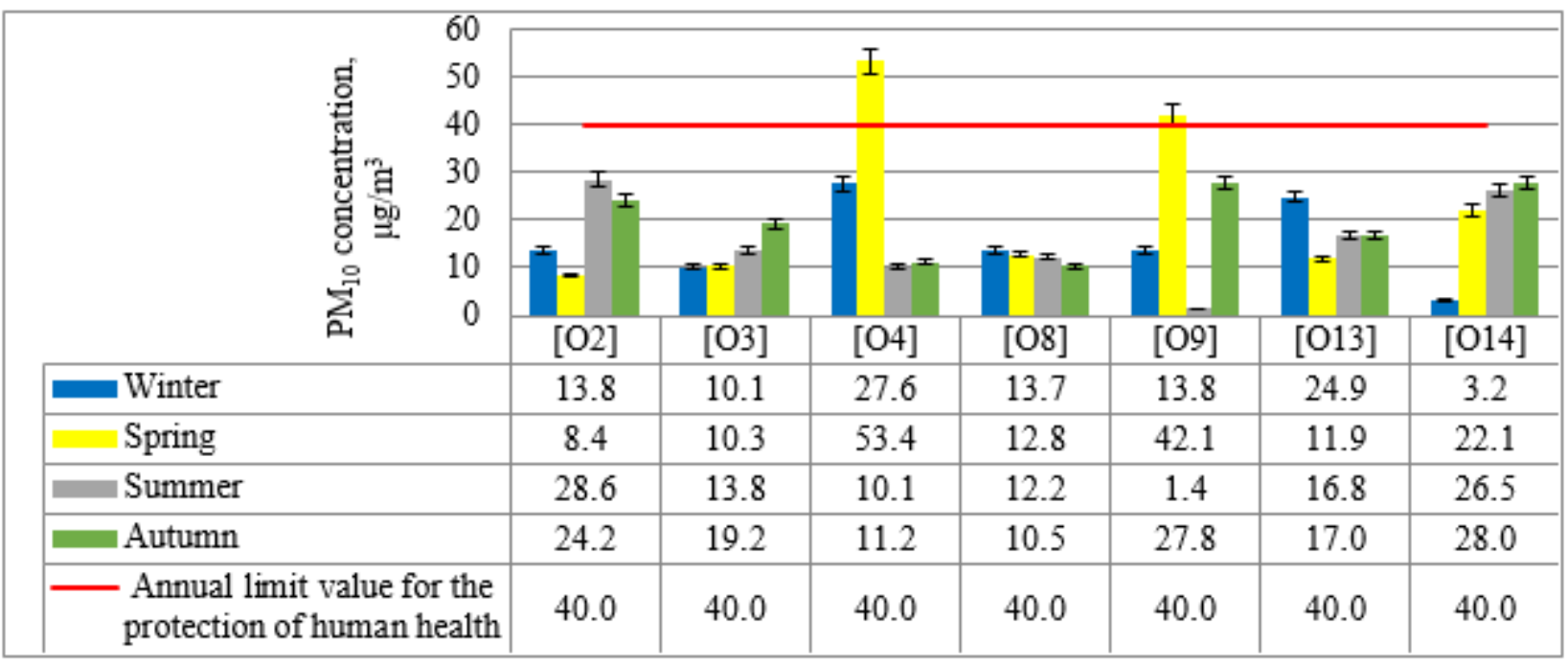

a

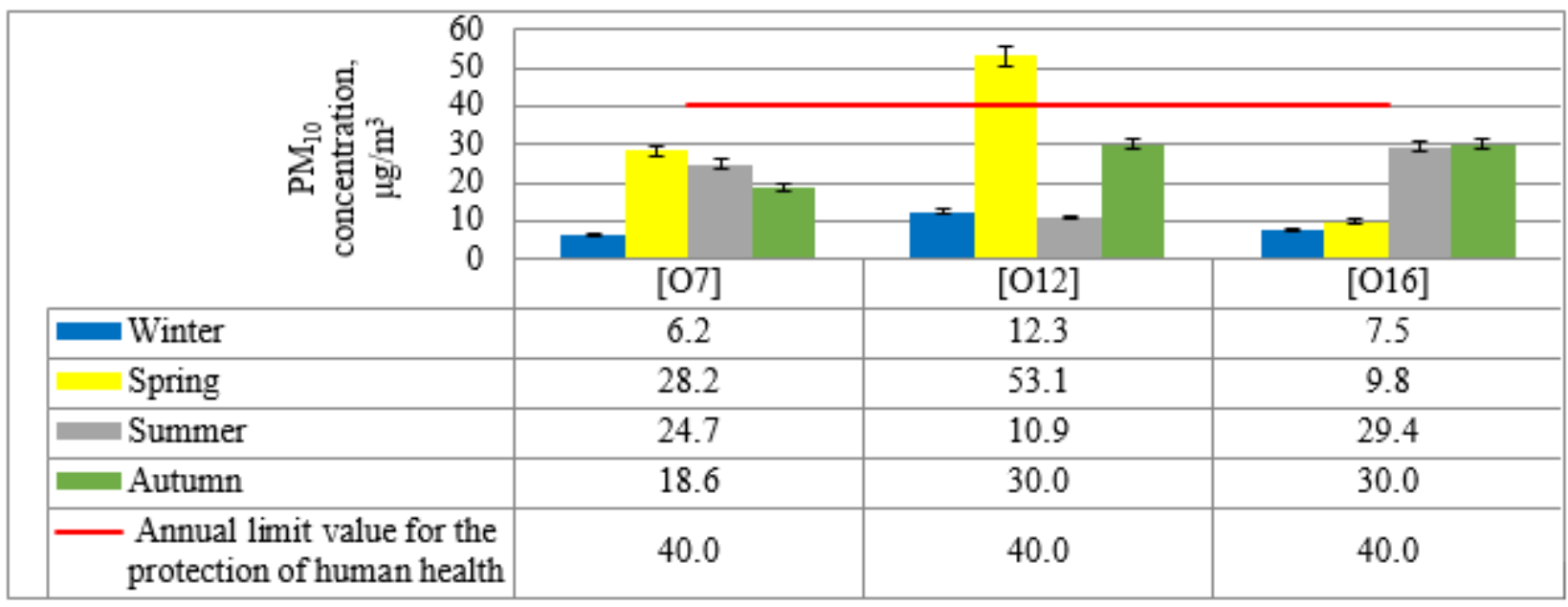

b

Figure 2

The annual concentration of particulate matter $\left(\mathrm{PM}_{10}\right)$ in the ambient air of Vilnius district: a - residential territory; b - recreation territory 


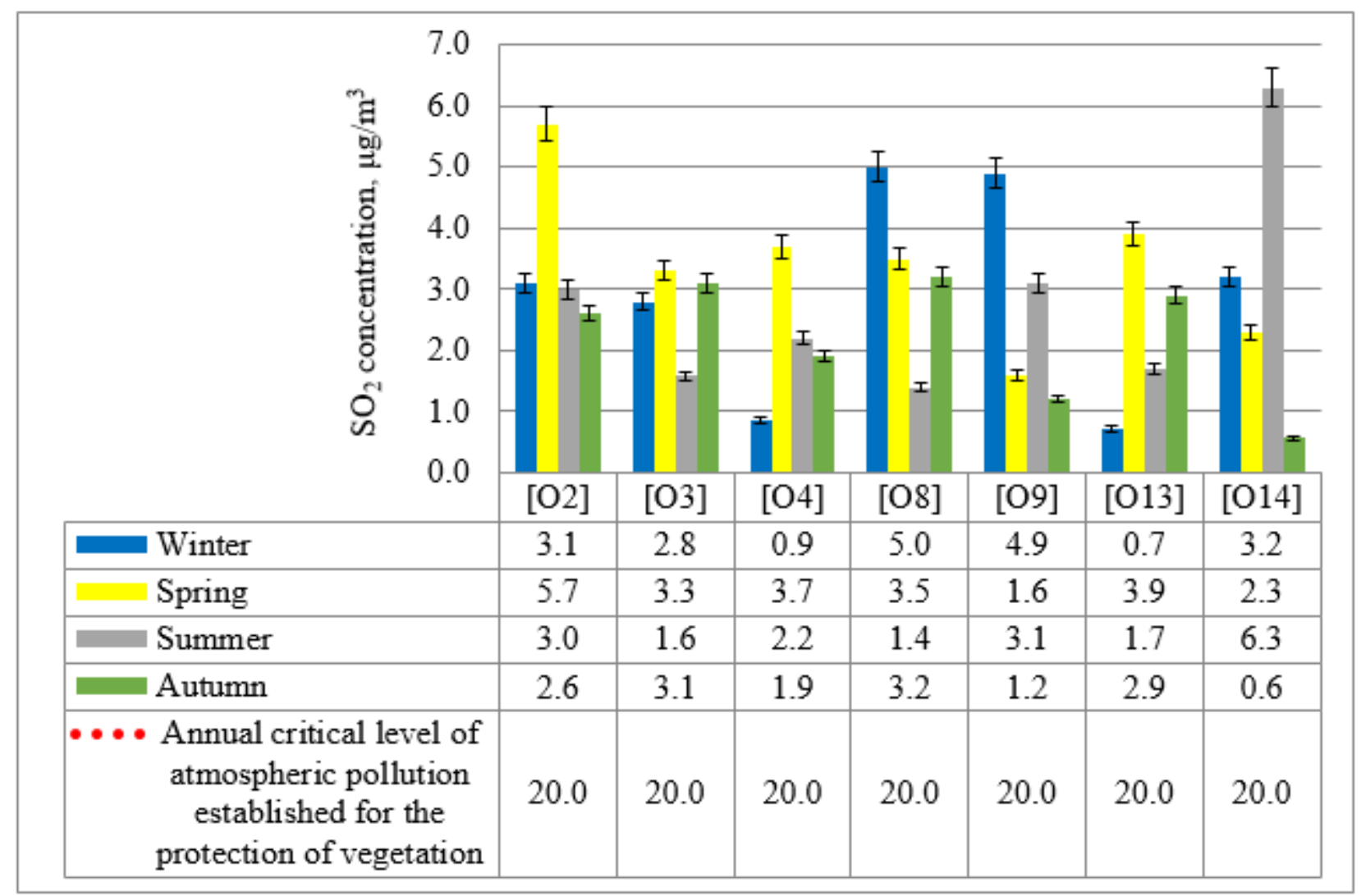

Figure 3

Sulfur dioxide $\left(\mathrm{SO}_{2}\right)$ concentration in the ambient air of the residential territory in Vilnius district 

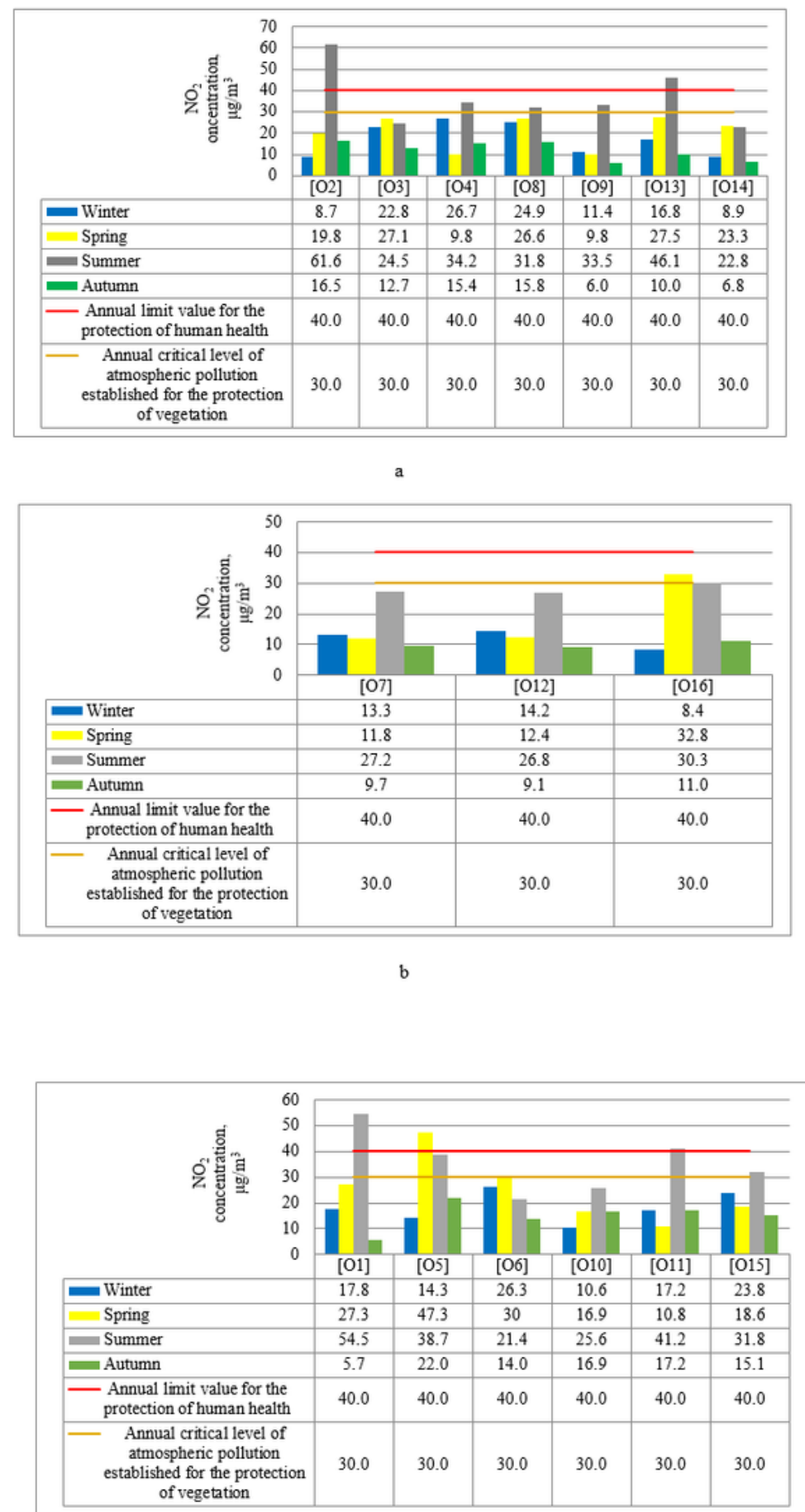

\section{Figure 4}

Nitrogen dioxide $\left(\mathrm{NO}_{2}\right)$ concentration in the ambient air of Vilnius district: a - residential territory; $b$ recreation territory; $\mathrm{c}$ - areas close to intense transport streets 


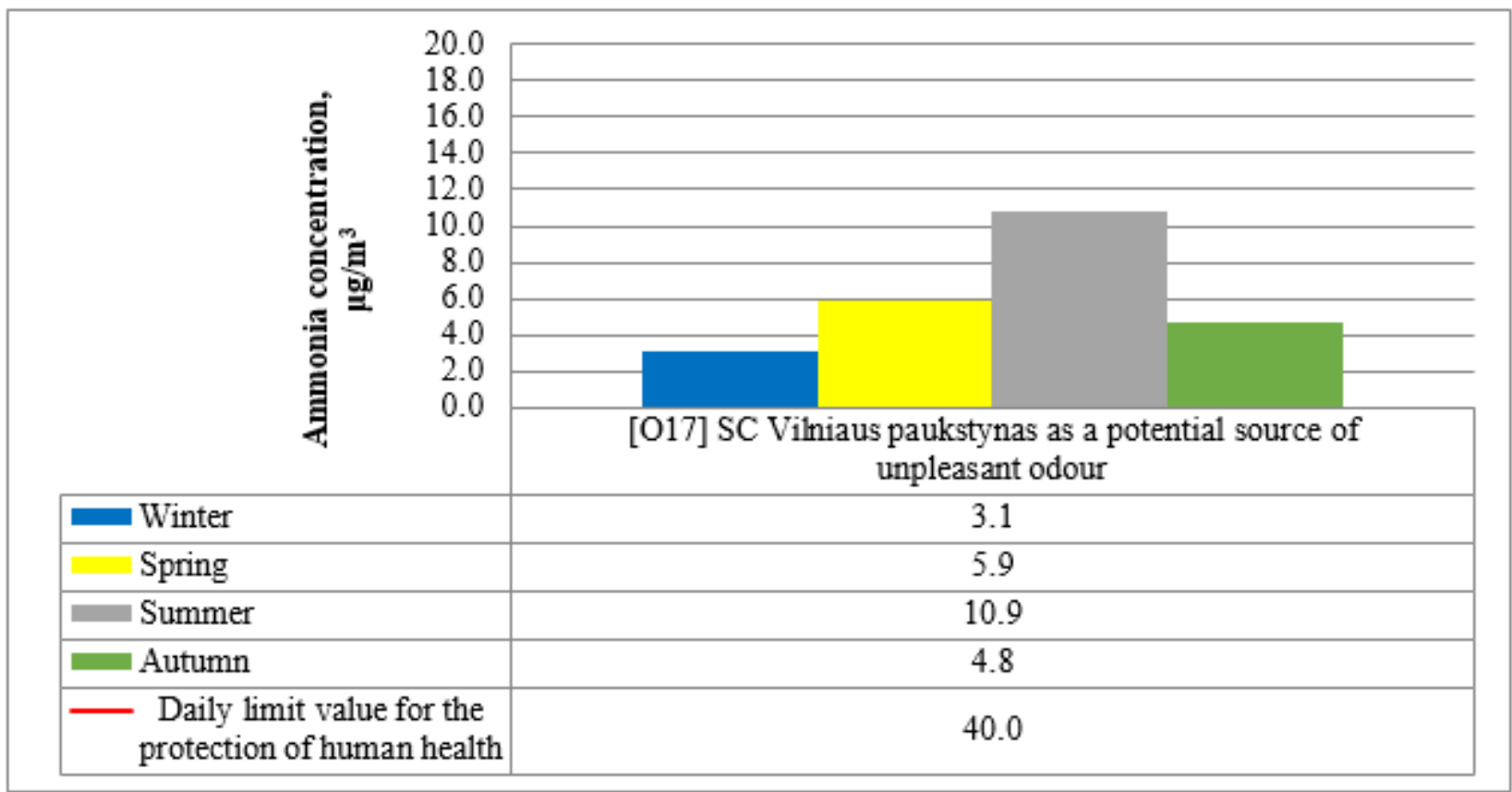

Figure 5

Daily concentration of ammonia in the ambient air of Vilnius district 